\title{
REFLEXES OF ANCIENT IDEAS ABOUT DIVINE TWINS IN THE IMAGES OF SAINTS GEORGE AND NICHOLAS IN BELARUSIAN FOLKLORE
}

\author{
Siarhei Sańko \\ Institute of Philosophy \\ National Academy of Sciences, Belarus \\ e-mail: siarhey.sanko@gmail.com
}

\begin{abstract}
As the images of Saint George and Saint Nicholas in Belarusian folklore converged, forming a non-canonical pairing, they assimilated a number of features indicative of an earlier tradition of divine twins' veneration. Specifically, the paper focuses on the following features: 1) the possible traces of the devatādvandva grammatical form and the dual number; 2) a special attitude towards horses; 3) Saints George and Nicholas accompanying (in the capacity of charioteers) a female deity or a mythological creature (Blessed Mother, Aurora); 4) Saints George and Nicholas accompanying a character who inherits the Thunderer's features (Saint Elijah, Saint Michael the Archangel); 5) systematic differences within a pair when one of the members is portrayed as a young man (Saint George) and the other one as an old man (Saint Nicholas); 6) the duplication of a single saint's image; 7) narratives of twin healers, one of whom functions as a surgeon and the other one as a thaumaturge.
\end{abstract}

Keywords: myths about twins, divine twins, paired saints, Saints George and Nicholas, twin healers

Grouping saints in pairs is a feature found in many European traditions. As early as the nineteenth century, Charles Cahier described different ways of grouping saints in Western European folk art and offered examples of paired saints (Cahier 1867: 453-463) and triads of saints (ibid.: 433-467). It is notable that the former are considerably more frequent than all the other grouping types (three, four, five, etc.). In a later analysis of saints' groupings in Celtic Christianity, Gilbert Doble argued that "there are numerous cases of dedications to Celtic saints being found in pairs. Thus dedications to S. David adjoin those to S. Nonna, while S. Winnow and S. Nectan, S. Mewan and S. Austol, S. Kea and S. Fili, S. Brioc and S. Marcan, seem to be always associated with each other" (Doble 1935: 43). He also suggested an alternative list of paired saints 
and noted that "the joint cult of SS. Mewan and Austol is a particularly striking example of this phenomenon" (Doble 1939: 16). The discussion of Celtic data can be found in Jankulak (2013 [2009]). A century ago, James Rendel Harris also suggested a connection between paired saints in European folklore and apocryphal literature with the ancient cult of "heavenly twins" (Harris 1903, 1906, 1913).

The same phenomenon of grouping saints existed in the cultural sphere of Russian Orthodoxy and sometimes manifested in canonisation (cf. the paired saints Anthony of the Caves and Theodosius of the Caves). This tendency is even more prominent in "folk Christianity" and is reflected in folklore texts of different genres. It is noteworthy that such grouping is often either entirely or mostly independent from both canonical and apocryphal hagiography. This tendency could not have been related to the spread of Christianity in Eastern Europe because it was not so prominent in the Byzantine Empire, where it stemmed from a persistent tradition of worshipping divine twins, which itself originated in the Greco-Roman world.

A prominent case of a saint pairing without a strong hagiographic influence in Belarusian folklore is the pair of Saints George and Nicholas. ${ }^{1}$ These saints invariably appear together in a vast body of folk charms which include enumerations of saints (often according to the folk calendar) and canonical saint pairings (Saints Cosmas and Damian, Florus and Laurus, Peter and Paul, Anthony and Theodosius, etc.), for example: “... Kuźma-Dziemian, ... Jahorja, i Mikola, ... Piatra-Paŭla, ...” (... Cosmas-Damian, ... George, and Nicholas, ... Peter-Paul, ...) (Romanov 1891b: 27, No. 90); “... śviatyj Jurij i śviatyj Mikola, i śviatyj Pavla j Piotra" (... Saint George and Saint Nicholas, and saints Paul and Peter) (ibid.: 77, No. 146); "Śviaty Jura, śviaty Mikola, i śviaty Antonij i Chviadosij, Illia i Pakrova" (Saint George, Saint Nicholas, and saints Anthony and Theodosius, Elijah and Pakrova $^{2}$ ) (Bartaševič 1992: 47, No. 61); "Śviaty Božy dzianiočak, Śviataja Subota, Śviataja Sluckaja Troica, Śviaty Ajciec Mikola, Śviaty Jurej-uhodničak Božy” (Holy God's Day, Holy Saturday, Holy Slutsk Trinity, Holy Father Nicholas, Saint George - God's chosen one) (Vasilievič \& Salaviej 2009: 200, No. 917).

It is interesting to note that the following features are not typical of the Russian tradition of charms: 1) enumerating saints in a calendar sequence (cf., for example, Maykov 1869: 76, No. 195; 114-115, No. 285; Vinogradov 1907: 53, No. 70; Vinogradov 1908: 23, No. 13; Vinogradov 1910: 8-9) and 2) grouping saints George and Nicholas even in a positional pair. Moreover, when George and Nicholas's names are listed in an enumeration not far from each other, they may be separated by some other saint or saints: 
Istinnyi Khristos i Bogoroditsa, Mater' Bozhiya, Mikhaile i Gavriile Arkhangeli Gospodni, Nikolae Chudotvorets, Vlasie, Sevatiyskii chyudotvorets, Georgie Khrabryi, Flore i Lavre, Merkurie Smolenskii, Averkii Yerapol'skii, Antonii, Feodosii Kiyevskie Pecherskie chyudotvortsy... (Vinogradov 1907: 53, No. 70)

True Christ and Dei Genetrix, the Mother of God, Michael and Gabriel the God's Archangels, Nikolaos the Wonderworker, Blaise the Wonderworker of Sebastea, George the Brave, Florus and Laurus, Mercury of Smolensk, Abercius of Hieropolis, Anthony, Theodosius of Kiev the Wonderworkers of the Caves...

Stoit velikii Nikolae Chyudotvorets ... Na gorakh kamennykh stoyu ya, rab bozhii (imya rek), poklonyayusya na vse chetyre storony Isusu Khristu, Vyshnemu Tvortsu, $i$ Khrabromu Georgiyu, $i$ arkhistratigu Mikhailu, i vsem nebesnym silam, Gavriilu i Koz'me i Domiyanu, i arkhidiyakonu Stevanu, i svyatym apostolom Petru i Pavlu, $i$ vsem svyatym apostolom. (Vinogradov 1908: 45, No. 42)

Great Nikolaos the Wonderworker is standing... I, God's slave (name), am standing on the stone rocks, bowing at all the four sides to Jesus Christ, Supreme Creator, and George the Brave, and Michael the Archistrategos, and all the powers of heaven, Gabriel and Cosmas and Damian, and Stephen the Archdeacon, and Saint Apostles Peter and Paul, and to all the Saint Apostles.

Umolyayu Tebya, istinnyi Khristos, Syn Bozhii, vsemiloserdnyi Bozhe, i Mater' Presvyataya Bogoroditsa, i svyatyi arkhangel Mikhail, groznyi voyevoda nebesnykh sil, svyatyi Georgii Khrabryi, i svyatye ugodniki Kossma i Damian, Nikolai chudotvorets, Vlasii, yepiskop Medostii Iyerusalimskii, Frol i Lavr, Merkulii Smolenskii, Averkii Iyerapol'skii, $i$ svyatye yevangelisty Matvei, Ioann, Luka $i$ Marko, $i$ svyatye ugodniki Antonii i Fedosii, kiyevskie chudotvortsy, kheruvimy $i$ serafimy $i$ vsya nebesnyia sily! (Maykov 1869: 114-115, No. 285).

I beg you, True Christ, the Son of God, God the All-Merciful and Holy Mother of God, and Saint Michael the Archangel, formidable commander of Heaven's forces, Saint George the Brave, and Saints Cosmas and Damian, Nikolaos the Wonderworker, Blaise, bishop Modestus of Jerusalem, Florus and Laurus, Mercury of Smolensk, Abercius of Hieropolis, and Saint Evangelists Matthew, John, Luke and Mark, and Saints Anthony, Theodosius the Wonderworkers of Kiev, cherubim, seraphim, and all the powers of Heaven! 
It should be noted here that academic discussion of the merging cults of the two saints was primarily based on Belarusian data (Anichkov 1892: 39-40; Uspenskiy 1982: 138-140). The repositories of paired saints in Belarusian and Russian charms overlap only partially. This could mean that the phenomenon of grouping saints in pairs continued into the period of Russian and Belarusian Orthodoxies' independent existence on ethnic Russian and Belarusian territory (at least, into the times of the Grand Duchy of Lithuania and the Polish-Lithuanian Commonwealth).

Saints George and Nicholas are much more often called upon together beyond these enumerations (see, for example, Romanov 1891b: 18-19, No. 50; 43, No. 158 ; 43, No. $160 ; 47$, No. 174 ; 82 , No. 168 ; 112 , No. 297 ; 137 , No. 2 ; 138 , No. 4; 139, No. 10; Bartaševič 1992: 56, No. 90; 62, No. 109; 64, No. 116; 65, No. 118; 344, No. 1185; Vasilievič \& Salaviej 2009: 199, No. 912; 200, No. 917; 471, No. 2323; 503, No. 2497).

If a saints' trio is called upon in a charm, then two of them generally appear as a pair in other cases. Saints George and Nicholas can be coupled with Saint Michael the Archangel in Belarusian charms: "śviatoha Jahorija ... śviatoha Mikalaja ... śviatoha Michajla" (Saint George ... Saint Nicholas ... Saint Michael) (Romanov 1891b: 183, No. 98; another variant in Vasilievič \& Salaviej 2009: 140, No. 606; 493, No. 2450), Saint Elijah: "Śviaty Mikola, Śviaty Juraj, Śviaty Illia" (Saint Nicholas, Saint George, Saint Elijah) (Vasilievič \& Salaviej 2009: 81, No. 274), and Holy Mary: "Śviaty Juraj, śviataja Mikola, matka Chrystova" (Saint George, Saint Nicholas, the Mother of God) (Bartaševič 1992: 312, No. 1051); "Śv. Jury, Śv. Mikola, matka Pakrova" (Saint George, Saint Nicholas, the Mother Pakrova) (Vasilievič \& Salaviej 2009: 265, No. 1230). There is a curious case when "Zaranica" (Aurora) takes the place of a female character: "Išoŭ śviaty Juraj ź Mikolam, stračaje zarnicu" (Saint George was walking with Saint Nicholas and met Aurora) (Bartaševič 1992: 344, No. 1185).

Saints George and Nicholas also appear together in Belarusian traditional calendar poetry: "Jurja i Mikola pa miežach chodziać, / Pa miežach chodziać, žyta rodziać" (George and Nicholas walk along the field edges / [They] walk along field edges, make the rye grow) (Bartaševič \& Salaviej 1980: 101, No. 61); “[Haspadar] Siadlaje kania vorana, / Jedzie ŭ polie žyta hliadzieć. / Spatykaje jaho Jurje ź Mikolaj: / - Nie jedź, panie haspadaru, / Tvajo žyta daŭno ahliedžana..." ([The master] saddles up a black horse, / Rides to the field to inspect the rye. / George and Nicholas meet him: / - Don't go, master, / Your rye was inspected long ago...) (Bartaševič \& Salaviej 1980: 87, No. 45); “Jurje, Mikola, / Abyjdzi žyta naŭkola, / I adamkni ziamlicu, / I vypuści rasicu” (George, Nicholas, / Walk around the rye, / And unseal the land, / And let the dew out) (Bartaševič \& Salaviej 1979: 173, No. 196); "A ty, Yurja, Mikola, / Abyjdzi žyta naŭkola" 
(And you, George, Nicholas, / Walk around the rye) (Bartaševič \& Salaviej 1979: 173, No. 195). Moreover, in the extensive body of Belarusian valačobnyja ${ }^{3}$ songs the plot revolves around the search for a missing fertility deity, a motif better known from surviving Hittite variants (Sańko 1994). In approximately half of the songs one of these paired saints (either George or Nicholas) represents the "fertility deity", while the other one tends to be the only character who is able to find the missing protector of good harvest and prosperity in the coming calendar cycle.

Saints George and Nicholas are portrayed as paired saints in a number of folk legends (Sheyn 1893: 360-362, No. 210; 367-370, No. 215; Romanov 1891a: 19-20, No. 15; 20-22, No. 15b; 66-67, No. 44; 163-165, No. 16). They also feature in proverbs related to the calendar cycle: "Jury z rasoj, a Mikola ź siaŭboj" (George is with the dew and Nicholas is with the sowing) (Fiadosik 1976: 99, No. 637); "Jury ź ciaplom, a Mikola z karmom" (George is with the warmth and Nicholas is with the fodder) (Fiadosik 1976: 99, No. 638); "Jury napjecca, i Mikola nie astajecca, da j Ivan by piŭ, kab chto kupiŭ" (George will get drunk, and Nicholas will follow him, and John would have drunk if someone had bought [him something to drink]) (Fiadosik 1976: 99, No. 639); "Skazaŭ śviaty Jurja: 'Ja žyty ǔradžu', a śviaty Mikola: 'Jak ja pahliadžu”' (Saint George said: 'I will grow rye' and Saint Nicholas [said]: 'As I will look after') (Fiadosik 1976: 99, No. 645); “Jury skazaŭ: 'Žyty ǔradžu'; Mikalaj adkazaŭ: 'Paždžy, pahliadžu"' (George said: 'I will grow rye' and Nicholas replied: 'Wait, I will look after') (Fiadosik 1976: 100, No. 645a); “Jury maścić, a Mikola hvaździć” (George makes it chilly, and Nicholas makes it frozen) (Fiadosik 1976: 113, No. 813); "Jury zamościć, Mikola zahruździć" (George will make it chilly, Nicholas will freeze the soil) (Fiadosik 1976: 113, No. 813a); "Viasnoju Heorhi, lietam Nikalaj z kormam, uvosień z mostam, zimoju z hvoździem" (In the spring it is George, in the summer it is Nicholas with fodder, with a chill in the autumn, with frost in the winter) (Fiadosik 1976: 113, No. 814), and also in ritual practices: "Na Mikolu kolas paśviačali, na Juryja - žyta” (On St. Nicholas's Day an ear [of rye] was consecrated, and on St. George's Day the [crop of] rye [was consecrated]) (Lopatin 2006: 294, No. 38).

One of the first scholars to investigate the reasons behind the convergence (up to the total merging) of the folk images of Saints George and Nicholas was Evgeniy Anichkov. He cited Saint Nicholas's “other vita” (Antonin 1873: 280; Leonid 1881: 61), which has an account of Saint Nicholas visiting Saint George's church and sacrificing oxen there (Anichkov 1892: 6), but he himself acknowledged the vulnerability of this evidence inasmuch as Saint Nicholas also visited other churches during his pilgrimage, where he also sacrificed oxen to other saints (ibid.: 7). What is more important is that hagiographic texts ascribed 
similar miracles to both saints (and also to Saints Nicetas and Theodore): the miracle of transference (delivering an enslaved young man from heathens), the miracle of prison liberation, the miracle of the servant who lost gold; although Anichkov ultimately argues that "this only proves the idea that the legends of Saints George, Theodore, Nicetas, and Nicholas developed in similar conditions" (ibid.: 9). Anichkov also noted that some stories about St. Nicholas incorporated the theme of dragon slaying (commonly associated with St. George).

Still, these similarities in most likelihood merely indicate what motifs were popular at the time when the respective vita variants emerged. Some of these motifs clearly are of pagan origin (including the dragon slaying).

It is likely that the real convergence of the images of these two saints occurred at the time of Ancient Rus'. The original variant of "Menology" that was included in the ancient Russian adaptation of the earlier Bulgarian "Streams of Gold" (Sreznevskiy 1867: 19-23, 26; Fomina 1984) includes a note that on 6 December (O.S.) there was "a miracle of Saint Nicholas and Saint Christian martyr George" (so-called "double miracle"), different versions of which subsequently became parts of various anthologies of Saint Nicholas's miracles (Makeyeva 2009). Turilov's idea that the "double miracle" had a Greek origin (that was transmitted via Bulgaria) (Turilov 1996) is still no more than a hypothesis, thus Uspenskiy's conclusion that the two saints' pairing is a uniquely Eastern Slavic phenomenon looks more plausible. This is all the more the case given that such merges are numerous and recurrent in folk culture and they are generally not motivated by a "double miracle" in theological and ecclesiastical literature.

It was already Anichkov who paid specific attention to Belarusian valačobnyja songs when discussing the reasons for the convergence of Saints Nicholas's and George's cults. He noted that "the performers of valačobnyja songs are of unsophisticated commoners: valačobniki who sang these songs on major holidays in front of houses' windows, of course, did not care to study the vita of a saint, but, on the contrary, sang about him what they learned from their immediate uneducated environment" (Anichkov 1892: 39). He also drew attention to the calendar proximity of the two saints' spring holidays and saw it as one of the reasons of their merging in folk tradition (ibid.).

I suggest that another important reason for this convergence both in charms and in folk songs was the older tradition of verbal and nonverbal veneration of "divine twins". So I consider it is necessary to focus on the possible traces of this twin mythology in the saints' images. Twin mythology was thoroughly discussed by James Rendel Harris (1906), Fernand Chapouthier (1935), Alexander Krappe (1936), Donald Ward (1968), Vyacheslav Ivanov and Vladimir Toporov (1983), and others. 


\section{POSSIBLE GRAMMATICAL INDICATORS OF SAINTS GEORGE AND NICHOLAS' PAIRING}

An analysis of ancient Russian literature shows that to designate special - "divine" or saint - pairs, forms of ancient dual number were used that are similar to what was known as devatādvandva (lit. "divine pair") in the ancient Indian language (Zholobov 1997, 1998; Zholobov \& Krys'ko 2001). In the Vedic tradition, it is extremely likely that it was the natural pairings of divine twins (such as Sky Father and Earth Mother, the Ashvins and Mitra-Varuna) that were originally referred to as devatādvandva in the Rigveda and the Atharvaveda (dyā'vāprthivī' 'Sky-Earth', mitrāvaruṇāu 'both Mitra and Varuna', aśvínāu 'both Ashvins'), which served as a model for similar references in other (originally non-twin) pairs. Oleg Zholobov argued that "when studying these facts, we cannot separate linguistic aspects from those of comparative mythology and the history of culture in general. In this particular case the interpretation of abovementioned illustrations as ancient Slavic examples of devatādvandva form corresponds entirely to their cultural status as venerated pairs. Nowadays we can consider it established knowledge that the pagan twin cult transformed into East and South Slavic veneration of sacred pairs" (Zholobov 1998: 51). This aspect was also highlighted by Vyacheslav Ivanov and Vladimir Toporov (Ivanov \& Toporov 1977: 115; Toporov 1989: 59-63 ff.).

Vitaliy Zaykovskiy emphasised that combining the saints' names into a single word (for example, Cosmas-Damian, Peter-Paul, Zosimus-Sabatius, GeorgeNicholas, etc.) in folklore texts reflects "the process of two names' integration into one devatādvandva-type name, a unified name that collocates with words in a singular form" (Zaykovskiy 1994: 56-59). In a paper on folk verses about Nikola Mokrush (St. Nicholas), Taisiya Khlybova tentatively suggested that the ancient literary dual number could have influenced the grammatical indicators of the feminine gender applied to male sacred characters: "In nominative, accusative and vocative cases of the dual number the declensional endings of masculine adjectives is "-as" (-aya) (for example: Raduytasya, Borise $i$ Glebe bogomudraya! <...> blazhennaya etc.), masculine verbs' dual number ends with the feminine inflexion - $a$ (nesla, khodila)." However, she ultimately favoured a different explanation of this phenomenon, saying: "In our opinion, the discrepancy between grammatical and natural gender in the verse is caused primarily by extralinguistic factors" (Khlybova 2007: 24). Six years earlier Svetlana Tolstaya had also highlighted this phenomenon:

The gender changes affected primarily male names of the feminine grammatical inflectional paradigm where a transfer to the feminine gender did not demand any formal modifications of the stem: 'Dve Mikoly u nas 
prazdnovali - zimnyaya i vesnovaya' (We celebrated two Nicholas's [days]: one in winter and one in spring), 'Varvara zavaryla, a Mykola zagvozdyla' (Varvara boiled and Nicholas froze), 'Svyataya Llya [Ilya]' (Saint Elijah), 'Llya nanesla gnillya' (Elijah brought rot), etc. (Tolstaya 2001: 57)

She noted that "they are a prominent testimony to the semantic disconnect between anthroponyms and original Christian reference; as a result, the category of the grammatical gender loses its real content (correlation with sex) and the anthroponym loses its onomastic function" (ibid.).

Such examples are indeed numerous in Belarusian folklore texts (Taisiya Khlybova cited primarily Belarusian examples). They mostly refer to Saint Nicholas (śviataja Mikola) and Saint Elijah (śviataja Illia), but can also be applied to Saint George's name: "Prošu ja i Jurju-Jahorju i Mikolu nadzieliajuščaho" (I also ask George and Nicholas the Giver) (Romanov 1891b: 48, No. 176). There is, however, one folk charm that most likely reflects the dual forms of masculine adjectives:

Śviaščennaja i votča načaĺnica Mikolaja, śviatyj božij uhodnik, vialikij čudotvorca, spasisia ob dušach našych. ... Śviatyj chrabryj Jahoraj, biari svoju zolotuju trubu ... Śviatyj prapodobnyj Chrolij, i ty žich spastyr, spasi jetu skocinu. Śviataja usierdnaja, $k$ vam pribehaju, Hospodi vyšnij Isusia Christe, synia božij, mać pračistaja, presviataja bohorodica. Śviataja mać pračistaja, spasi ž jetu skocinu ... I prosim śviatoho Mikolu, božaho uhodnička čudotvorca: śviatyj Mikola čudotvorac, spasi jetu skocinu... (Romanov 1891b: 46, No. 169)

Sacred and fatherly chief Nicholas, God's Saint, the great Wonderworker, take care of our souls ... Holy brave George, take your golden trumpet ... Saint Reverend Florus, you are their shepherd, take care of this stock. Holy zealous, I am turning to you, Holy God Jesus Christ, the Son of God, Blessed Mother, Our Lady, Holy Mother, save this stock ... And we ask Saint Nicholas, God's Saint the Wonderworker, to take care of this stock...

The charm's text is obviously contaminated with fragments of other charms used to strengthen the power of magical text. This is reflected in the double appeal to Saint Nicholas in different grammatical forms and the "incorrect" appeal to Saint Florus without mentioning Saint Laurus. The latter two saints only appear in charms as a pair. Thus we should attribute the words "Śviataja usierdnaja" (Holy zealous) to "Śviaščennaja i votča načaĺnica Mikolaja ... Śviatyj chrabryj Jahoraj" (Sacred and fatherly chief Nicholas ... Holy brave George), suggesting that the grammatical "incorrectness" reflects some formulas based on devatādvandva. This example is important because the name Nicholas does 
not fall into the feminine grammatical inflectional paradigm and, therefore, the usage of the feminine grammatical gender in this case ("Śviaščennaja i votča načaĺnica Mikolaja”) requires an alternative explanation to the one cited earlier by Svetlana Tolstaya. The suggestion that devatādvandva formulas might be reflected in this case could seem far-fetched were there no other hints of this ancient model's influence on the charms' texts. The folk image of paired saints Boris and Gleb is an interesting case. Strangely, while the pairing was very prominent in ancient Russian literary culture, it had almost no reflection in folk charms. This image is absent from Russian charms anthologies that were used for this study (by Maykov and Vinogradov), and its transformed variant is mentioned just twice in Belarusian texts and only in the enumerations that follow the calendar order (Romanov 1891b: 27-28, No. 90, 92). This means that the charms borrowed it from the folk calendar and not from the literary tradition. It is important that in both cases these paired saints are represented in the texts by only one of the brothers, Boris, whose name is pluralised: "Śviatyja Hanny, Borisa, Makavja - christovy dzianiočki" (Saint Anns, Borises, Maccabees - Christ's days) (Romanov 1891b: 27, No. 90); "pomolimsia śviatym Borisam, Hannam, Makavju, śviatomu Spasytalku...” (let's pray to Saints Borises, Anns, Maccabees, Holy Saviour ...) (Romanov 1891b: 28, No. 92).

In the first case the dual number (Borisa) is used, while in the second case it is plural (Borisam). This is reminiscent of the use of the elliptical dual number model to name divine twin pairs, dvandva ekaśeșa (Sanskrit ekaśeșa 'ellipsis') as in Vedic mitrā 'Mitra-Varuna' (lit. "both Mitras"). It could transform into plural if the dual number lost its independent grammatical meaning, for example, in Greek Aïavte "Ajaxes" (i.e., "Ajax (Aias) and Teucer"), Latin Castores (i.e., Castor and Pollux) and Cereres (i.e., Ceres and Proserpina) (Bremmer 2008: 60; Puhvel 1977: 404; Wackernagel 1905 [1896]: 151), cf. Latin patres and Belarusian baćkí where the elliptical dual number was replaced by plural. A similar form is presumed to have existed in the Hittite language. The elliptical dual number is not replaced mechanically by plural, but could be reinterpreted as single (Puhvel 1969: 61-62).

Therefore, it is logical to see the first example as an elliptical dual number and regard "Borisa" as "(oba) Borisa" (both Borises), i.e., Boris and Gleb. The inconsistency in transforming the dual number into plural, which was noted by Puhvel, may be at play in the cases when the Boris and Gleb holiday is referred to as a singular word, for example, Boris (Tolstaya 2005: 41).

This transformation and the interpretation of twin and divine pairs as a whole could have resulted in using the singular form in cases when SS. George and Nicholas act together: "Jurje, Mikola, / Abyjdzi žyta naŭkola, / I adamkni ziamlicu, / I vypuści rasicu" (George, Nicholas, / Walk around the rye, / And 
unseal the land, / And let the dew out) (Bartaševič \& Salaviej 1979: 172-173, No. 196, also No. 195). The same tendency can be observed in charms: “...budzia jechać śviaty Jury i Mikola, budzia vas sabirać i miečču halovy adsiakać” (Saint George and Nicholas will come, will call you together and cut the heads with a sword) (Bartaševič 1992: 125, No. 345).

\section{SS. GEORGE AND NICHOLAS' SPECIAL ATTITUDE TOWARDS HORSES}

It is well known that classical "divine twins" (the Greek Dioscuri and the Vedic Ashvins) had a special attitude towards horses:

In each of the Indo-European traditions, the association of the Divine Twins with the horse represents the most pronounced characteristic of the twin brethren. Moreover, the striking agreement in detail revealed by the various traditions makes it evident that this association dates back at least to the period of Indo-European unity. (Ward 1968: 11-12)

So it does not require any detailed additional comment.

Both George and Nicholas are regarded as the guardians of horses in folk culture. As a rule, on these saints' days in spring people tried to take their horses to the pasture for the first time either during the day ("na Jurjevu rasu"; "on George's dew”) or at night ("na Mikoĺskuju travu"; "on Nicholas's grass"). It depended on when spring started and on the proximity to the full moon. Belarusian valačobniki used to sing about it: "Kaniušok boha prosić: / - Pasi ž, boža, maich koni, / Maich koni ǔ čystym poli, / U čystym poli, u Jurjevych rosach, / U Jurjevych rosach, u Mikoĺskich travach" (A young groom asks God: / God, graze my horses, / My horses in an open field, / In an open field, in George's dews, / In George's dews, in Nicholas's grasses) (Bessonov 1871: 9-10).

The traces of the ancient theriomorphic veneration of divine twins are also worth mentioning. The Vedic Ashvins (Aśvinī, lit. "possessors of horses” or "related to horses") were given birth by Saranyū who took the form of a mare (cf.: the protagonist of "The Horse's Son" folk tale was given birth by a mare). The

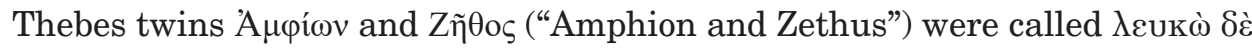

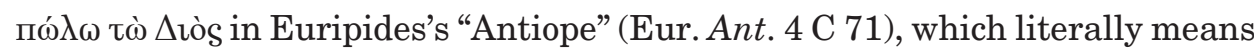
"a pair of Zeus's white stallions". A similar statement can be found in "Heracles":

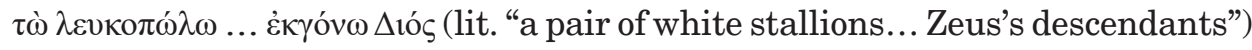
(Eur. Her. 29), even though the epithet $\lambda \varepsilon v \kappa o ́ \pi \omega \lambda \mathrm{("white-horsed")} \mathrm{referred} \mathrm{to}$ another pair of divine twins - Kastor and Polydeuces (Ward 1968: 12; Nikolayev 2012: 123). 
Lyuben Karavelov claimed that Belarusians venerated Saint George in the form of a horse (Karavelov 1861: 215). This claim was also cited in Boris Uspenskiy's work (Uspenskiy 1982: 139). However, it is evidently based on an inaccurate interpretation of a song fragment cited without a character representing the Belarusian sound “ $y$ ” (“ŭ”) (reinstated in square brackets): "Razyhra[ŭ] sia jur[j]ja[ŭ] konik / Zalacieńki konik" (George['s] the horse played much / The golden horse), cf. "Razhuliaŭsia Jurjeŭ koń, / Razbiŭ kamień kapytom" (George's horse played much / Broke a stone with his hoof) (Bartaševič and Salaviej 1979: 173, No. 197). In a fuller variant of this song, the actions of George's horse acquire cosmogonic connotations:

Ǔ čystym poli pad javarom Razhuliaŭsia Jurjï̌ koń.

Razhuliaŭsia Jurjï̌ koń, Chvastom mora raskalychaŭ. Chvastom mora raskalychaŭ, Kapytom kamień razbivaŭ. (Mažejka 1981: 83, No. 36)
In an open field under a maple Yury's horse immersed in play. George's horse immersed in play, Churned the sea with his tail, Broke a stone with his hoof.

In a fairy tale these actions are performed by an anthropomorphic protagonist in order to get the egg containing Koschei's ${ }^{4}$ death:

Jak daŭ liaskaj svajoj pa mory - dabivajecca da taho, što holy kamušak lia jaho. Jak udaryŭ liaskaj pa kamušku, tak kamušak hety razliacieŭsia! Tojčas vutka z kamuška, koršun za jaje da jamu daŭ! Jon uziaŭ hetu vutku, raździor jaje papalam. I jajco heta za pazuchu zaklaŭ. (Bandarčyk 1973: 200)

He hit the sea with his mace and kept hitting until just a stone was left in front of him. As he hit that stone with his mace, the stone broke to pieces. In that instant, a duck flew [out of the stone], but a hawk intercepted it and gave the duck to him. He took the duck and tore it in two halves. And he put this egg under his shirt.

The cosmogonic nature of this type of tales is revealed in another tale's opening:

Heta bylo z pačatku śvieta. Žyŭ Kaščej Biaśśmiertny, i bahatyroŭ usich pabiŭ, i valšebnikaŭ usich pahubiŭ, i ŭkraŭ sonca, $i$ miesiačka, $i$ zorački, i stala ciomna liudziam. (Bandarčyk 1973: 66)

This was at the beginning of time. There lived Koschei the Deathless and he beat all the heroes and killed all the wizards and stole the sun, the moon and the stars, and darkness fell onto people. 
These two motifs (churning of the ocean and breaking the original rock) also appear in a different form in cosmogonic myths of Ancient India. Consequently, George's horse also alludes to cosmogony as it is described as a cosmic animal whose body parts correspond to parts of the Universe:
Jaho konik chvaślivy,
His boastful horse,
Chvastom vulku padmiacie. ...
Will sweep the street with his tail. ...
Vuškami nieba padapre,
Vočkami zory paličyć,
Will prop up the sky with his ears,
Vočkami zory paličyć,
Will count the stars with his eyes,
Will count the stars with his eyes,
Ciabie, maladoha, padvialičyć Will bring glory to you, young man
(Bartaševič \& Salaviej 1979: 173, No. 200)

For comparison, there is a similar but more detailed description of a sacrificial horse in "Bṛhad-āraṇyaka Upanuṣad" (BAU I.1.1) (Radhakrishnan 1968 [1953]: 149).

Two antagonistic characters of Belarusian demonology have hippomorphic features. They were described by Pavel Shpilevskiy (Pavel Drevlyanskiy). One of them is Kumelgan. It is an evil spirit that harms household horses. It was depicted as a creature which had a human body covered with wool, a horse's head, and hoofs on his hands and feet. The second one is called Vazila. He had a humanlike form but with horse ears and hoofs. (Drevlyanskiy 1846: 85-87, 99-101). While existing critique of Shpilevskiy's accounts suggests that they cannot be regarded as a reliable source of Belarusian folklore and mythology (Toporkov 2002: 253-254; Levkiyevskaya 2002: 348-349), no persuasive arguments have been forwarded against the existence of these particular characters. As I have suggested elsewhere (Sańko 2011), these characters may reflect some (partially demonised) features of the "substrate" (Baltic) twins, which later carried over to paired saints George and Nicholas.

It is also important that in both the folk imagination and iconography saints George and Nicholas are depicted as horsemen on white horses (see, for example, Anichkov 1892: 19 on St. Nicholas). With regard to their pairing, a Belarusian charm against snakes is of interest, as Saint George appears there as a double:

... budu prasić śviatoje Jurja i Jahorja. Pryjedzieć śviaty Jury i Jahory na bielym kani, voźmieć try pruty miednych, try pruty zialieznych i pahonić vas na zialiezny tok, i budzieć bić, prabivać i skroź ziemliu prahaniać. (Bartaševič 1992: 136, No. 386)

I will ask Saints Jurja and Jahorja ${ }^{5}$. Saints Jurja and Jahorja will come on a white horse, will take three copper rods and will chase you to the iron barnyard, and will beat, crash, and drive [you] through the ground. 
Many valačobnyja songs emphasise the special relationship between George and Nicholas, on the one hand, and their relation to horses, on the other hand. If one of the members of the pair (either George or Nicholas) is missing, it is only the other one (either Nicholas or George) who can find him, precisely because he owns a horse, unlike other saints:

Da na tych kresličkach da ŭsio praźnički

Rachavalisia, sabiralisia,

Adnaho praźnička nie daždalisia.

Jakoha praźnička? - Śviatoha Mikolu.

Kaho syskać pa Mikolu paslać?

Pietryka syskać pa Mikolu paslać.

Pietryk im adkazyvaje:

- Ja kania nie maju, Mikolu nie znaju.

Nu kaho syskać pa Mikolu paslać?

Illiu syskać pa Mikolu paslać.

Illia ža im adkazyvaje:

- Ja kania nie maju, Mikolu nie znaju.

Aslaviŭsia śviaty Jury:

- Ja konika maju, Mikolu znaju.

Tolki Jury kania siadlaje,

Konika siadlaje, z dvara zjazdžaje,

Z dvara zjazdžaje, Mikolu strakaje

(Bartaševič \& Salaviej 1980: 183, No. 97; variants No. 105, 106, 112, 115, $116,117,119,120$, etc.).

So on these chairs all the holidays

Were gathering and counting each other,

One holiday was missing.

Which one? Saint Nicholas.

Who is to be sent to find Nicholas?

Peter is to be sent to find Nicholas.

Peter replies to them:

- I do not have a horse, I do not know Nicholas.

So who is to be sent to find Nicholas?

Elijah is to be sent to find Nicholas.

Elijah replies to them:

- I do not have a horse, I do not know Nicholas.

Saint George calls:

- I have a horse, I know Nicholas. 
Just as George saddles up a horse,

Saddles up a horse, rides from the backyard,

Rides from the backyard, meets Nicholas.

A similar emphasis on a connection to horses can be found in other paired saints' images, in particular Florus and Laurus, and Boris and Gleb. In Belarusian folklore, this connection manifests differently in the case of George and Nicholas than it does with other paired saints. But the very multiplicity of paired saints who possess a connection to horses points to the influence of an ancient mythological matrix, which persisted for a long time, filling the opening gaps with characters from the newer, folk Christian lore. In this context, it is characteristic that another pair of saints, not hagiographically bound, emerged: that of Chrol (Florus) and Jahorja (George), instead of the canonical pair of SS. Florus and Laurus: "Na Chrala i Jahorja nia tkuć i ni pashuć" (You cannot weave and plow on Florus's and George's [days]) (Dobrovol'skiy 1894: 46).

\section{SS. GEORGE AND NICHOLAS AND TWIN CHARIOTEERS}

It was already Macdonell who noted that despite having very little connection to horse riding in the Vedic tradition, the Ashvins are often described as charioteers whose chariot is more often drawn not by horses but by birds (Macdonell 2002 [1897]: 50). Many hymns in the Rigveda and Atharvaveda depict the Ashvins riding a chariot that carries the daughter of solar deity Surya (Sūryā) or the goddess of dawn Ushas (Ușas).

Particularly interesting are the hymns where the Ashvins act as matchmakers who take Surya's daughter to her bridegroom's home: "Having become pleased, the young girl, the Daughter of the Sun, has now mounted your chariot, o men" (RV 1.118.5ab) (Jamison \& Brereton 2014: 276), "The Aśvins were the wooers of Sūryā and Agni was the leader. // Soma was the bridegroom; the Aśvins were both wooers" (RV X.85.8cd-9ab) (Jamison and Brereton 2014: 1522).

Belarusian valačobnyja songs contain a strikingly similar adaptation of this mythological theme. The only difference is that they focus not on a female deity's marriage but on the birth of God's Son (more on it in Sańko 2016: 42-43):

Za tymi vazami jechala kareta,

Muliavanaja, vyzlačanaja,

To ž a ŭ toj karecie sam Haspoža.

Sam Haspoža, Matka Božža,

Matka Božža i Pračystaja, 
Jana pryjazdžala, sama pavitala, Da na koničku na bulanieńkim, A śviaty Jury za pavoźnička, Śviataja Mikola za pamočnička (Sheyn 1874: 98, No. 147)

A coach drove behind those carts, [It was] painted and gilded, And Our Lady herself was in that coach. Our Lady herself, the Mother of God, The Mother of God, the Most Pure, She arrived, she herself greeted [them], On a brown horse, And Saint George was a coachman, Saint Nicholas was a helper.

Tudym jechala pračystaja, Jana jechala šaśćma kaniami, Šaśćma kaniami ŭsio bulanymi, Karetami maliavanymi, Katočkami ŭsio kovanymi. Śviaty Juryj za pavoźnička, Śviataja Mikola za lahodnička, A śviaty Illia viadzieć kania.

(Bessonov 1871: 4, No. 3; cf. Sheyn 1874: 83, No. 141)

There went the most pure, She rode six horses, Six horses, all of them brown, On painted coaches, On forged wheels. Saint George was a coachman, Saint Nicholas was a friend And Saint Elijah guided the horse.

The Indian and Belarusian examples cited above are also interesting because they refer to a specific aspect of divine twin mythology. 


\section{SS. GEORGE AND NICHOLAS AS PART OF DIVINE (SACRED) TRIADS}

Apart from the abovementioned examples from songs, the association of George and Nicholas with female characters is frequent in charms: "Śviaty Juraj, śviataja Mikola, matka Chrystova" (Saint George, Saint Nicholas, Christ's Mother) (Bartaševič 1992: 312, No. 1051); "Śv. Jury, Śv. Mikola, matka Pakrova" (Saint George, Saint Nicholas, the Mother Pakrova) (Vasilievič \& Salaviej 2009: 265, No. 1230); "Išoŭ śviaty Juraj ź Mikolam, stračaje zarnicu" (There went Saint George with Nicholas, they met Aurora) (Bartaševič 1992: 344, No. 1185).

In comparative studies of Indo-European mythology much research has been conducted on the connection between divine twins and female deities, mostly the Daughter of the Sun (ancient Indian "duhitá süryasya", Lithuanian: "sáulès duktèldukrytè", Latvian "saules meita", "the Sun Virgin") and the morning dawn

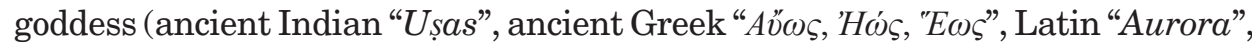
etc.) (Ward 1968: 10-11; West 2007: 227 ff.; Janda 2006: 6). (See Chapouthier 1935 for a detailed analysis of the genesis of this motif and its reflection in the art of classical antiquity.)

Certain parallels found in charms, riddles, and songs indicate that the folk image of the Blessed Mother may have appropriated some features of the preChristian solar goddess: "Zara-zaranica, krasnaja dziavica, pa niebu chadzila, kliučy ŭranila, jak sonca ǔzyjšlo i kliučy najšlo" (Venerable Aurora ${ }^{6}$, a beautiful girl, was walking around the sky, dropped her keys; as the Sun rose, it found the keys) - the answer to the riddle is "dew" (Fiadosik 1972: 46, No. 235, variants No. 227-234), "Ivańkina mamka ŭsiu nočku nie spala, / Usiu nočku nie spala: u Piotry kliučy krala, / Ziemliu razmykala, rasu vypuskala” (John's mother didn't sleep the entire night, / didn't sleep the entire night: she was stealing keys from Peter, / Unlocked the land, let the dew out) (Lis \& Taŭlaj 1985: 213, No. 436, variant No. 682); "Išoŭ sam Haspodź ź niebiasa, zhubiŭ zalatyja kliučy z-pad pajasa. Macier Božaja išla, zalatyja kliučy znajšla" (The Lord himself came from heaven, lost the golden keys from his pocket. God's Mother was walking, found the keys) (Bartaševič 1992: No. 1119), cf. "Miesiac kliučy pahubiŭ, sonca ŭstala, kliučy ŭkrala" (The moon lost the keys, the Sun rose, stole the keys) (Fiadosik 1972: 46, No. 230).

Another persistent association is between SS. George and Nicholas and male Thunderer characters. In the examples above it is exclusively Saint Elijah. The connection with him can also be found in charms texts: "Śviaty Mikola, Śviaty Juraj, Śviaty Illia, / Spasi ad hromu mianie" (Saint Nicholas, Saint George, Saint Elijah, / Save me from thunder) (Vasilievič \& Salaviej 2009: 81, No. 274). Here is another one: "Kacilasia zlata kareta, / U karecie try praźnički: / Pieršy 
praźnik - Jahor chrabior, / Druhi praźnik - Mikola śviatoj, / Jašče praźnik Illia-prarok" (A golden coach was driving, / There were three holidays in the coach: / The first holiday is George the Brave, / The second holiday is Nicholas the Holy, / The last holiday is Elijah the Prophet) (Bartaševič \& Salaviej 1980: No. 12).

However, it is Michael the Archangel who normally possesses the Thunderer's features in charms' texts: “Budu ŭ Boha prasić śviatoha Michajla-archaniela i z hrazoj, i ź pierunom, i z daždžom" (I will ask God for Saint Michael the Archangel with a thunderstorm, and lightning, and the rain) (Bartaševič 1992: 113, No. 307). Saints George and Nicholas go well together with him: “... pryjedzie sam Haspodź sa svaimi apostalami: ź Jurjem, ź Mikolam, ź Michajlam, z Archajlam. Jon vas pierunom pabje, malankaj papalie" (... God himself will come together with his apostles: with George, with Nicholas, with Michael the Archangel. He will strike you with thunder, will burn you with lightning) (Vasilievič \& Salaviej 2009: 140, No. 606); "śviatoha Jahoryja ... śviatoha Mikalaja ... śviatoha Michajla" (Saint George... Saint Nicholas... Saint Michael) (Romanov 1891b: 183, No. 98).

The associations of divine twins with the Thunderer in religions of classical antiquities and non-European nations were meticulously studied by Alexander Krappe (1936). He particularly focused on the triad of Prussian gods at the sanctuary of Romov and outlined several features of twin pairs that are relevant for the present study.

Krappe argued that in a divine pair of twins one is depicted as a young man and the other as an old man; moreover, one is shown as a patron of spring and the other as a patron of autumn and winter (Krappe 1936: 6-8).

\section{SYSTEMATIC DIFFERENCES BETWEEN ST. GEORGE AND ST. NICHOLAS}

Based on his analysis of Renaissance-era texts, Krappe defined the key triad within the traditional comparative framework: Perkuns - Juppiter, Potrimps Castor, Pikuls (Patollo) - Pollux (Krappe 1936: 7), making no distinction between the abovementioned Bardoayts and Potrimps. Vladimir Toporov refined Krappe's juxtaposition by linking the epithet Bardoayts ("bearded") with Patols and, consequently, with the lower world and the sphere of the dead (Ivanov \& Toporov 1983: 170). This idea is also supported by the following text:

[D]as eine war wie ein man junger gestalt ane bardt, gekronett mit sangelen und frolich sich irbot und der gott vom getreide und hies Potrimppo ... Das dritte bilde war ein alter mahn mit einem langen groen bardt und 
seine farbe gantz totlich, war gekronet mit einem weissen tuche wie ein morbant unde sag von unden auff die andern an unde his Patollo mit namen. (Grunau 1876: 77)

One was [the image] of a young-looking man without a beard, crowned with rye ears and with a happy look on his face, the god of grain, called Potrimpo ... The third was the image of an old man with long green beard and an absolutely deathly face colour, crowned with a linen turban-like bandage, who looked down at [two] others and was called Patollo.

It is also very important that there was a heraldic shield under the banner that contained images of the god. It was supported by two white horses standing on their hind legs, and on the shield itself one could see a bear-headed man. Thus in this composition we can see the triad in a theriomorphic code with a twin pair, symbolized by the two white horses.

This is how the Milanese represented their patrons, twin saints Gervasius and Protasius: the first one had a long white beard and the second one was a beardless youngster (Krappe 1936: 8).

If we compare the Prussian pair of saints to their Belarusian counterparts, it is obvious that Potrimpo corresponds to St. George and Patollo corresponds to St. Nicholas. A significant feature of St. Nicholas's iconography is indeed his old age, baldness, and grey beard. A valačobnaja song reads: "A Mikola, stary chaziain, / Pa miežach chodzić, / Žyta raŭnuić" (And Nicholas, the old master, / Walks along the field edges, / Cares for the rye) (Bartaševič \& Salaviej 1980: No. 94). When Nicholas and George had an argument over which one of them a man greeted ("zdrastuj daŭ", lit. "gave a greeting"), Nicholas said: "Mnie daŭ, bo ja čalaviek stary" (He said it to me, because I am an old man) (Hrynblat \& Hurski 1983: 122, No. 139). However, when asked which one of the two is more handsome, the man replied: "Nie, bratcy, abai charašy, usio roŭna jak braty adnaho atca-maciery" (No, brothers, you both are good-looking, as if you were children of the same father and mother) (ibid.: 125, No. 140).

There is one feature that brings Prussian Potrimpo even closer to Belarusian St. George. A highly probable etymology of the name Potrimpo derives from the Lithuanian word "trempti" (to trample). But it is not merely because he walks on the surface of the earth and, thus "trampling" on it, in contrast to the underworld Patollo (Ivanov \& Toporov 1992: 293). We should also take into consideration George's mythical function which was thus reflected in Belarusian folklore: "Dzie Jura stupaje - žyta vyliahaje, / A dzie Jura chodzić - usio zbožža rodzić, / Dzie Jura nahoju - tam žyta kapoju" (Where George steps, rye straightens up, / And where George walks - all grain fructifies, / Where George [puts his] foot - rye is abundant) (Bartaševič \& Salaviej 1980: No. 106). Therefore, we may conclude that "trampler" Potrimpo was stepping on the soil to awaken 
its fertile powers in spring (Ivanov \& Toporov 1983: 170). Moreover, ritualistic stamping that was often accompanied by tapping was an integral part of many dances and circle dances in spring and summer.

Saint Nicholas and Patollo, for their part, share a relation to the underworld (see Uspenskiy 1982: 70-72 on St. Nicholas).

Krappe noted that the different functions of characters within a pair are connected to a particular duplicity of the characters themselves. He supported Grunau's idea that Potrimpo correlates to spring Saturn and Patollo correlates to winter Saturn (Krappe 1936: 8). Ivanov and Toporov drew such parallels as spring and autumn Jarilo (George), spring and autumn Nicholas, Roman rituals dedicated to Mars in spring and autumn (Ivanov \& Toporov 1983: 170-171). This duplicity additionally manifested in the images of old and young Avsen (Toporov 1988) and young and old George.

\section{SS. GEORGE AND NICHOLAS AND THE IDEAS OF TWIN HEALERS}

The belief that divine twins can and will help people in case of disasters and misfortunes, such as shipwrecks, natural disasters, epidemics, and other diseases was very widespread (Bracken 1935; Hankoff 1977; O'Connor \& Hufford 2001). Indo-European cultures especially valued the healing abilities of divine twins (including Dioscuri, Ashvins, Asclepius, Apollo's son (Apollo was a twin himself), Erichthonius's twin brother, the father of twins Machaon and Podalirius who were doctors during the Trojan War) (Hankoff 1977: 308).

There are several texts in Belarusian folklore in which these ideas are reflected in a particular way. Pertinently to the present discussion, some of them mention Saints George and Nicholas as miraculous healers. These are the legends "The doctor", "The cripple and the blacksmith", and "Nicholas and the priest", which were published by Romanov (1891a: 60-79). One other text which comes from the Mogilev Province tells of a poor soldier who shares his dinner three times with two grey-haired old men, each time offering each of them "deniažcy" (money) as alms. Then he meets two gentlemen riding a carriage drawn by a pair of horses. The soldier offers to be their "coachman"; the gentlemen call themselves "doctors" and take it upon themselves to cure the czar's ailing daughter. The way of healing described in these texts is notable: one of the "doctors" who was sitting "s levyje ruki" (on the left-hand side), sharpened the knife, cut all the body parts of the sick girl, put them in a bathtub full of warm water, rinsed them, put them in a bathtub with cold water, then dried all the parts with a rag and re-assembled them in the correct order on the table. 
Then the second "doctor", who was sitting on the right-hand side, blew air three times through the body and revived the princess (Romanov 1891a: 71). In other variants of this tale only one of the characters ("beggar", "Nicholas") treats her this way, while the other one ("blacksmith", "priest") secretly watches him do it. "Nicholas" refers here to paired saint helpers George and Nicholas and the "blacksmith" refers to another popular folk Christian pair: twin blacksmiths Cosmas and Damian who are also famous for being doctors (see also Anichkov 1892: 49). In one of the texts George and Nicholas play the role of two old beggars, even though this variant lacks the healing part. The texts that mention only Nicholas as a doctor may reflect the archaic tradition of naming the entire pair by one of the brothers' names (see above).

The distribution of the functions between the Belarusian "doctors" mirrors that of their more famous counterparts: Asclepius's sons, twin god Apollo's grandsons Machaon and Podalirius. Eitrem regarded these "two brother doctors" together with some other ancient Greek paired characters as a manifestation of divine twins (Eitrem 1902: 92-98). Already Aristides compared doctor brothers Machaon and Podalirius with Dioscuri (Haudry 1992: 357). It is worth men-

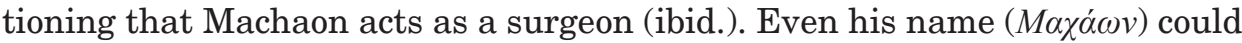
be related to $\mu \alpha \dot{\chi} \alpha \iota \rho \alpha$ "(sacrificial, cooking) knife; blade" (Doederlein 1850: 202; Höfer 1894-1897: 2231), because he used one to cut arrows from the wounds (Hom. Il. XI.844). On the other hand, Podalirius acts rather as a magic healer, using medicine and possibly charms. He is able to "diagnose invisible illnesses and cure incurable ones" (Haudry 1992: 357, 359).

It may be assumed that in the Belarusian legends under consideration, the distribution of functions between Nicholas and George was as follows: Nicholas was a surgeon and George was a thaumaturge (magic healer), but this requires further studies.

The limited scope of the paper does not allow me to analyse some other features of Saint George's and Saint Nicholas's pairing that can be traced to earlier ideas about divine twins. But even the folk ideas about God's helpers George and Nicholas outlined above give us a reason to suggest that they were influenced by an earlier mythological paradigm. This does not mean that the two saints functioned and were perceived as actual twins in folk culture, since folk texts contain no indications they were represented as the sons of the same couple. Compare, however, on the one hand: "Nie, bratcy, abai charašy, usio roŭna jak braty adnaho atca-maciery" (No, brothers, you both are good-looking, as if you were children of the same father and mother) (see above), and the presentation of at least one of the members of the pair, George, as a younger member of a divine family in this valačobnaja song, on the other hand: "Za maim stalom sam boh siadzić. / Piervy kubak - dlia samoha boha, / A druhi kubak - dlia žany jaho, / Treci kubak - dlia Jurja śviatoha" (The God himself 
sits at my table. / The first cup is for the God himself, / The second one is for his wife, / the third cup is for Saint George) (Bartaševič \& Salaviej 1980: 71, No. 27). Here Saint George takes the position that is occupied by the master's children in similar songs: "Zielianoje vino - panu haspadaru, / Čornaje piva - dlia žany jaho, / Saladok miadok - dlia jaho dzietak" (Green vine is for the master, / Black beer is for his wife, / Sweet honey is for his children) (Bartaševič \& Salaviej 1980: 63, No. 18, variants No. 21, 26, 115). These tendencies could not have formed a stable twin complex in the framework of folk Christianity, as many features of divine twins were distributed (and often duplicated) among other popular paired saints, mainly Cosmas and Damian, Peter and Paul, Boris and Gleb, Florus and Laurus, Anthony and Theodosius. Only the complete inventory of all these traits and their comprehensive interpretation will allow us to restore the crucial traits of ancient mythological matrix, including its regional modifications. This study attempts to define such features based on the image of SS. George and Nicholas in Belarusian folklore, which are not represented in the same way in any other parts of Eastern Europe.

\section{ACKNOWLEDGEMENTS}

The article was written as part of a project financed by the Foreign Ministry of Estonia through the Developmental Cooperation Programme (66-2015-A).

\section{NOTES}

1 In the Belarusian folk tradition, the names of saints are pronounced as follows: Saint George - Śviaty Jury (variants Jura, Jurja, Juraj, Jurej, Jahoryj, Jahorja and some others), Saint Nicholas - Śviaty Mikola (variant Mikalaj).

2 The feast of the Intercession of the Theotokos or the Protection of Our Most Holy Lady Theotokos and Ever-Virgin Mary is called Pakrova/Pokrova in Belarus and Ukraine and Pokrov in Russia. These titles are also used as a name of the personified holiday or Mother of God herself.

3 In Belarus the songs that are performed during the Easter Day celebration by groups of singers wandering between villages (valačobniki) are called valačobnyja peśni.

4 Koschei the Deathless in East Slavic folk tales is an archetypal immortal abductor of the hero's wife or bride.

5 As I noted above, both names denote the same character and are not translated here.

${ }^{6}$ In Belarusian texts Zara may designate most likely the Dawn goddess and is to be translated as Aurora. Zaranica is a diminutive form of Zara. This double appeal is to express a special veneration of the goddess. 


\section{REFERENCES}

Anichkov, Evgeniy 1892. Mikola Ugodnik i sv. Nikolai. [Mikola the Saint and St. Nicholas.] Zapiski Neo-Filologicheskogo obshchestva. [Notes of the Neo-Philological Society.] Vol. 2, No. 2, p. 55.

Antonin, arkhimandrit 1873. Yeshchio o svyatitele Nikolaye Mirlikiyskom. [More on Prelate Nicholas of Myra (in Lycia).] Trudy Kiyevskoi dukhovnoi akademii. [Works of the Kiev Theological Academy.] Vol. IV, No. 12, pp. 241-288.

Bandarčyk, Vasiĺ (ed.) 1973. Čaradziejnyja kazki. [Fairy Tales.] Vol. 1. Minsk: Navuka i technika.

Bartaševič, Halina (ed.) 1992. Zamovy. [Charms.] Minsk: Navuka i technika.

Bartaševič, Halina \& Salaviej, Lija (eds.) 1979. Viesnavyja piesni. [Spring Songs.] Minsk: Navuka i technika.

Bartaševič, Halina \& Salaviej, Lija (eds.) 1980. Valačobnyja piesni. [Easter Songs.] Minsk: Navuka i technika.

Bessonov, Piotr 1871. Belorusskiye pesni, s podrobnym obyasneniyem ikh tvorchestva $i$ yazyka, s ocherkami narodnogo obryada, obychaya i vsego byta. [Belarusian Songs with a Detailed Explanation of Their Expression and Language, with Notes on Folk Ritual, Custom and Way of Life.] Moscow: Tipografia Bakhmeteva.

Bracken, Helmut von 1935. Zwillinge als Zauberärzte und Heilgötter. Ciba Zeitschrift, Vol. 23, pp. 780-782.

Bremmer, Jan N. 2008. Greek Religion and Culture, the Bible and the Ancient Near East. Leiden \& Boston: Brill.

Cahier, Charles 1867. Caractéristiques des saints dans l'art populaire. Tome Second. Getc. Paris: Libraire Poussielgue frères. Available at http://gallica.bnf.fr/ark:/12148/ bpt6k5784430n, last accessed on 10 April 2018.

Chapouthier, Fernand 1935. Les Dioscures au service d'une déesse: étude d'iconographie religieuse. Paris: E. de Boccard.

Doble, Gilbert Hunter 1935. Saint Meriadoc: Bishop and Confessor, Patron of Camborne. Truro: Netherton and Worth.

Doble, Gilbert Hunter 1939. Saint Mewan and Saint Austol: Patrons of the Parishes of St. Mewan and St. Austell, Cornwall. Long Compton: King's Stone Press.

Dobrovol'skiy, Vladimir 1894. Smolenskiy etnograficheskiy sbornik. [Ethnographic Anthology of Smolensk.] Vol. III: Poslovitsy. [Proverbs.] St. Petersburg: Tipografia S. N. Khudekova.

Doederlein, Ludwig 1850. Homerisches Glossarium. Bd. I. Erlangen: Ferdinand Enke. Drevlyanskiy, Pavel 1846. Belorusskie narodnye poverya: Statya vtoraya. [Belarusian Folk Beliefs: The Second Paper.] Pribavleniya $k$ Zhurnalu Ministerstva narodnogo prosveshcheniya. [Appendix to the Journal of the Ministry of Folk Education.] Vol. 3, pp. 85-125.

Eitrem, Samson 1902. Die göttlichen Zwillinge bei den Griechen. Christiania: A. W. Brøggers Buchdruckerei. Available at https://bildsuche.digitale-sammlungen. de/index.html?c=viewer\&bandnummer $=$ bsb00067463\&pimage $=4 \& v=100 \&$ nav $=$ $\& \mathrm{l}=\mathrm{de}$, last accessed on 10 April 2018.

Fiadosik, Anatoĺ (ed.) 1972. Zahadki. [Riddles.] Minsk: Navuka i technika.

Fiadosik, Anatoĺ (ed.) 1976. Prykazki i prymaŭki ŭ dzviuch knihach. [Proverbs and Sayings in Two Books.] Book 1. Minsk: Navuka i technika. 
Fomina, Mariya 1984. Zhanrovye i syuzhetnokompozitsionnye osobennosti drevnerusskogo literaturnogo sbornika "Zlatostruj". [Genre and Plot Composition Peculiarities of the Ancient Russian Literary Anthology "Zlatostruj".] Voprosy syuzheta i kompozitsii. [Issues of Plot and Composition.] Gorky: Gor'k. gos. un-t im. N. I. Lobachevskogo, pp. 14-19.

Grunau, Simon 1876. Simon Grunau's preussische Chronik. Bd. I. Leipzig: Verlag von Duncker \& Humblot. Available at http://www.mgh-bibliothek.de/dokumente/a/ a016932+0001.pdf, last accessed on 10 April 2018.

Hankoff, Leon D. 1977. Why the Healing Gods Are Twins. The Yale Journal of Biology and Medicine, Vol. 50, No. 3, pp. 307-319. Available at https://www.ncbi.nlm. nih.gov/pmc/issues/174258/, last accessed on 10 April 2018.

Harris, J. Rendel 1903. The Dioscuri in the Christian Legends. London: C. J. Clay and Sons. Available at https://archive.org/details/cu31924099385084, last accessed on 10 April 2018.

Harris, J. Rendel 1906. The Cult of the Heavenly Twins. Cambridge: The University Press. Available at https://archive.org/details/cultheavenlytwi00harrgoog, last accessed on 10 April 2018.

Harris, J. Rendel 1913. Boanerges. Cambridge: Cambridge University Press. Available at https://archive.org/details/boanerges00harr, last accessed on 10 April 2018.

Haudry, Jean 1992. Podalire et Machaon. Lalies: Actes des sessions de linguistique et de littérature, Vol. 10 (Aussois, 1988 \& 1989), pp. 355-363.

Höfer, Otto 1894-1897. Machaon. In: W. H. Roscher (ed.) Ausführliches Lexikon der griechischen und römischen Mythologie. Leipzig: Druck und Verlag von B. G. Teubner, pp. 2228-2231.

Hrynblat, Majsiej \& Hurski, Anton (eds.) 1983. Liehiendy i padanni. [Legends and Traditions.] Minsk: Navuka i technika.

Ivanov, Vyacheslav \& Toporov, Vladimir 1977. Strukturno-tipologicheskiy podkhod $\mathrm{k}$ semanticheskoy interpretatsii proizvedeniy izobrazitel'nogo iskusstva v diakhronicheskom aspekte. [Structural-Typological Approach to Semantic Interpretation of Fine Art Works in a Diachronic Aspect.] Trudy po znakovym sistemam. [Works on Sign Systems.] Vol. VIII, pp. 103-119.

Ivanov, Vyacheslav \& Toporov, Vladimir 1983. K probleme ltsh: Jumis i baltiyskogo bliznechnogo kul'ta. [On the Issue of Latvian Jumis and Baltic Twin Cult.] Baltoslavyanskiye issledovaniya 1982. [Baltic-Slavic Studies 1982.] Moscow: Nauka, pp. 140-175.

Ivanov, Vyacheslav \& Toporov, Vladimir 1992. Patols. [Patols.] In: S. Tokarev (ed.) Mify narodov mira: Entsiklopediya. T. 2. K-Ya. [Myths of Peoples around the World: Encyclopedia.] Moscow: Sovetskaya Entsiklopediya, p. 293.

Jamison, Stephanie W. \& Brereton, Joel P. (transl.) 2014. The Rigveda: The Earliest Religious Poetry of India. 3 volumes. Oxford \& New York: Oxford University Press.

Janda, Michael 2006. The Religion of the Indo-Europeans. In: K. Jones-Bley \& M. E. Huld \& A. D. Volpe \& M. Robbins Dexter (eds.) Proceedings of the Seventeenth Annual UCLA Indo-European Conference, Los Angeles, October 27-28, 2005. Washington: Institute for the Study of Man, pp. 1-29.

Jankulak, Karen 2013 [2009]. Adjacent Saints' Dedications and Early Celtic History. In: S. Boardman \& J. R. Davies \& E. Williamson (eds.) Saints' Cults in the Celtic World. Woodbridge, UK \& Rochester, N.Y.: The Boydell Press, pp. 91-118. 
Karavelov, Lyuben 1861. Pamyatniki narodnogo byta bolgar. [Records of the Bulgarian Folk Way of Life.] Book 1. Moscow: Tipografiya K. Andersa.

Khlybova, Taisiya 2007. Stikh o Nikole Mokrushe. [Poem about Nikola Mokrush.] Zhivaya starina. [Living Antiquity.] No. 2, pp. 22-26.

Krappe, Alexander H. 1936. Les dieux jumeaux dans la religion germanique. Acta Philologica Scandinavica, No. 6, pp. 1-25.

Leonid, arkhimandrit 1881. Zhitiye i chudesa sv. Nikolaya Mirlikiyskogo i Pokhvala yemu: Issledovaniye dvukh pamyatnikov drevney russkoy pismennosti XI veka. [Vita and Miracles of Nicholas of Myra in Lycia and a Panegyric to Him: A Study of Two Records of Russian Writing of the 11th Century.] St. Petersburg: Tipografiya V. S. Balashova.

Levkiyevskaya, Yelena 2002. Mekhanizmy sozdaniya mifologicheskikh fantomov v "Belorusskikh narodnykh predaniyakh" P. Drevlyanskogo. [The Mechanisms of Mythological Phantom Creation in "Belarusian Folk Traditions" by P. Drevlyanskiy.] In: A. L. Toporkov et al. (comps.) Rukopisi, kotorykh ne bylo: Poddelki $v$ oblasti slavyanskogo fol'klora. [Manuscripts That Never Existed: Counterfeits in the Field of Slavic Folklore.] Moscow: Nauchno-izdatel'skiy tsentr "Ladomir", pp. 311-351.

Lis, Arsienij \& Taŭlaj, Halina (eds.) 1985. Kupaĺskija i piatroŭskija pieśni. [St John's Day and St. Peter's Day Songs.] Minsk: Navuka i technika.

Lopatin, Gennadiy 2006. Kul't sv. Nikolaya po sovremennym belorusskim svidetel'stvam. [St. Nicholas's Cult According to Modern Belarusian Testimonies.] Palaeoslavica, Vol. XIV, pp. 287-313.

Macdonell, Arthur A. 2002 [1897]. Vedic Mythology. Delhi: Motilal Banarsidass Publishers.

Makeyeva, Irina 2009. Chudesa Nikolaya Chudotvortsa o saratsine v russkoy pis'mennosti. [Nikolay the Wonderworker's Miracles of Saracen in Russian Literature.] Trudy otdela drevnerusskoy literatury. [The Works of the Ancient Russian Literature Department.] Vol. 60, pp. 3-28.

Maykov, Leonid 1869. Velikorusskiye zaklinaniya. [Great Russian Incantations.] St. Petersburg: Tipografiya Maykova.

Mažejka, Zinaida 1981. Pieśni bielaruskaha Paazierja. [Songs of Belarusian Poozer'e.] Minsk: Navuka i technika.

Nikolayev, Aleksandr 2012. "Gimn Dioskuram” Alkeya. [Alcaeus' "Hymn to Dioscuri".] Aristey: Vestnik klassicheskoy filologii i antichnoy istorii. [Aristeas: Philologia classica et historia antiqva.] Vol. V, pp. 114-140. Available at https://scholar. harvard.edu/files/nikolaev/files/nikolaev_gimn_dioskuram.pdf, last accessed on 10 April 2018.

O'Connor, Bonnie B. \& Hufford, David J. 2001. Understanding Folk Medicine. In: E. Brady (ed.) Healing Logics: Culture and Medicine in Modern Health Belief Systems. Logan: Utah State University Press, pp. 13-35. DOI: 10.2307/j.ctt46nwrq.5.

Puhvel, Jaan 1969. Hittite annaš šiwaz. Zeitschrift für vergleichende Sprachforschung. Bd. 83, H. 1, pp. 59-63. Available at http://www.jstor.org/ stable/40849411?seq=1\#page_scan_tab_contents, last accessed on 10 April 2018.

Puhvel, Jaan 1977. Devata-Dvandva in Hittite, Greek, and Latin. The American Journal of Philology, Vol. 98, No. 4, pp. 396-405. http://dx.doi.org/10.2307/293802. 
Radhakrishnan, Sarvepalli 1968 [1953]. The Principal Upanișads. London: George Allen \& Unwin Ltd. Available at https://archive.org/stream/ PrincipalUpanishads/129481965-The-Principal-Upanishads-by-SRadhakrishnan\#page/n5/mode/2up, last accessed on 10 April 2018.

Romanov, Yevdokim 1891a. Belorusskiy sbornik. [Belarusian Anthology.] Vol. 4: Skazki kosmogonicheskiye i kul'turnye. [Cosmogonic and Cultural Tales.] Vitebsk: Tipolitografiya G. A. Malkina.

Romanov, Yevdokim 1891b. Belorusskiy sbornik. [Belarusian Anthology.] Vol. 5: Zagovory, apokrify i dukhovnyye stikhi. [Charms, Apocrypha, and Religious Verses.] Vitebsk: Tipo-litografiya G. A. Malkina.

Sańko, Siarhiej 1994. Siužet “pra źniklaha boha”: hiecka-kryŭskija (bielaruskija) paralieli. [The "Missing God" Plot: Hittite-Belarusian Parallels.] Kryŭja: Crivica. Baltica. Indogermanica, No. 1, pp. 5-24.

Sańko, Siarhiej 2011. Kumiaĺhan. [Kumilgan.] In: T. Valodzina \& S. Sańko (eds.) Mifalohija bielarusaŭ: Encyklapiedyčny sloŭnik. [Belarusian Mythology: Encyclopedic Dictionary.] Minsk: Bielaruś, pp. 259-260.

Sańko, Siarhiej 2016. Heniealohija i hermienieŭtyka matyvu "Mifičnaja istota na drevie" ŭ zamoŭnych tekstach: svietapohliadny i kamparatyŭny aspiekty. [Genealogy and Hermeneutics of the Motif of a "Mythic Creature on the Tree" in Incantation Texts: Worldview and Comparative Aspects.] Bielaruski falklor: Materyjaly i dasliedavanni. [Belarusian Folklore: Materials and Research.] Vol. 3, pp. 10-52.

Sheyn, Pavel 1874. Belorusskiye narodnyye pesni, sotnosyashchimisya $k$ nim obryadami, obychayami i suyeveriyami, s prilozheniyem obyasnitel'nogo slovarya i grammaticheskikh primechaniy. [Belarusian Folk Songs with Relevant Rituals, Customs, and Superstitions, Supplemented by an Explanatory Glossary and Grammar Notes.] St. Petersburg: Tipografiya Maykova.

Sheyn, Pavel 1893. Materialy dlya izucheniya byta i yazyka russkogo naseleniya SeveroZapadnogo kraya. [Materials for the Study of Ways of Life and Language of the Russian Population of the North-Western Region.] Vol. II: Skazki, anekdoty, legendy, predaniya... [Tales, Jokes, Legends, Traditions...] St. Petersburg: Tipografiya Imperatorskoy akademii nauk.

Sreznevskiy, Izmail 1867. Svedeniya $i$ zametki o maloizvestnykh $i$ neizvestnykh pamyatnikakh. [Information and Notes about Little-Known and Unknown Records.] I-XL. St. Petersburg: Tipografiya Imperatorskoy akademii nauk.

Tolstaya, Svetlana 2001. Antroponimy v narodnoi kalendarnoi terminologii: (Na primere polesskogo narodnogo kalendarya). [Anthroponyms in Folk Calendar Terminology (on the data from Polesian folk calendar).] Izvestiya Ural'skogo gosudarstvennogo universiteta. [Reports of the Ural State University.] No. 20, pp. 54-59.

Tolstaya, Svetlana 2005. Polesskii narodnyi kalendar'. [Polesian Folk Calendar.] Moscow: Indrik.

Toporkov, Andrey 2002. O "Belorusskikh narodnykh predaniyakh" i ikh avtore. [On "Belarusian Folk Traditions" and Their Author.] In: A. L. Toporkov et al. (comp.) Rukopisi, kotorykh ne bylo: Poddelki v oblasti slavyanskogo fol'klora. [Manuscripts That Never Existed: Counterfeits in Slavic Folklore Field.] Moscow: Nauchnoizdatel'skiy tsentr "Ladomir", pp. 245-254.

Toporov, Vladimir 1988. Avsen' i “Avsenevy” teksty v svete rekonstruktsii. [Avsen and "Avsen's" Texts in Light of Reconstruction.] Etnolingvistika teksta: Semiotika 
malykh form fol'klora. [Ethnolinguistics of Text: The Semiotics of Small Folklore Forms.] T. I: Tezisy i predvaritel'nye materialy $k$ simpoziumu. [Abstracts and Preliminary Materials of the Symposium.] Moscow, pp. 16-21.

Toporov, Vladimir 1989. Ideya svyatosti v Drevnei Rusi: vol'naya zhertva kak podrazhaniye Khristu - Skazaniye o Borise i Glebe. [The Idea of Holiness in Ancient Rus': Free Sacrifice as the Imitation of Christ: The Legend about Boris and Gleb.] Russian Literature, Vol. XXV (1), pp. 1-102.

Turilov, Anatoliy 1996. Vizantiyskii i slavyanskii plasty v "Skazanii inoka Khristodula" ( $\mathrm{k}$ voprosu o proiskhozhdenii pamyatnika). [Byzantine and Slavic Layers in "The Story of Enoch Khristodul" (on the Issue of the Work's Origin).] In: G. Litavrin (ed.) Slavyane i ikh sosedi. [The Slavs and Their Neighbours.] Issue 6. Grecheskii $i$ slavyanskii mir $v$ sredniye veka $i$ ranneye novoye vremya: $S b$. statei $k$ 70-letiyu akademika G. G. Litavrina. [Greek and Slavic World in the Middle Ages and Early Modern Time: The Collection of Papers in Honour of Academician G. G. Litavrin's 70th Birthday.] Moscow: Indrik, pp. 81-99.

Uspenskiy, Boris 1982. Filologicheskiye razyskaniya v oblasti slavyanskikh drevnostei (Relikty yazychestva $v$ vostochnoslavyanskom kul'te Nikolaya Mirlikiyskogo). [Philological Research in the Field of Slavic Antiques (The Remnants of Paganism in the East Slavic Cult of Nicholas of Mura in Lycia)]. Moscow: Izd-vo Moskovskogo un-ta. Vasilievič, Uladzimir \& Salaviej, Lija (eds.) 2009. Zamovy. [Charms.] Minsk: Bielaruś. Vinogradov, Nikolay 1907. Zagovory, oberegi, spasitel'nye molitvy i proch. [Charms, Amulets, Salvatory Prayers, etc.]. Vol. I. St. Petersburg: Tipografiya I. N. Kushnereva i Ko.

Vinogradov, Nikolay 1908. Zagovory, oberegi, spasitel'nye molitvy i proch. [Charms, Amulets, Salvatory Prayers, etc.]. Vol. II. St. Petersburg: Tipografiya I. N. Kushnereva i Ko.

Vinogradov, Nikolay 1910. Zagovory, oberegi, spasitel'nye molitvy i proch. [Charms, Amulets, Salvatory Prayers, etc.] Vol. III. St. Petersburg: Tipografiya I. N. Kushnereva i Ko.

Wackernagel, Jacob 1905 [1896]. Altindische Grammatik. Bd. II, 1. Einleitung zur Wortlehre: Nominalkomposition. Göttingen: Vandenhoeck \& Ruprecht.

Ward, Donald 1968. The Divine Twins: An Indo-European Myth in Germanic Tradition. Berkeley \& Los Angeles: University of California Press.

West, Martin L. 2007. Indo-European Poetry and Myth. Oxford: Oxford University Press. Zaykovskiy, Vitaliy 1994. Narodnyi kalendar' vostochnykh slavyan: Vospriyatie vremeni cherez personifitsirovannye prazdniki, obyedinennye v pary. [East Slavic Folk Calendar: The Perception of Time through Paired Personified Holidays.] Etnograficheskoye obozreniye, No. 4, pp. 53-65.

Zholobov, Oleg 1997. Drevnerusskoye dvoystvennoye chislo v obshcheslavyanskom kontekste. [Ancient Russian Dual Number in General Slavic Context.] Kazan: Unipress.

Zholobov, Oleg 1998. Simvolika i istoricheskaya dinamika slavyanskogo dvoystvennogo chisla. [Symbolism and Historical Dynamics of the Slavic Dual Number.] Frankfurt am Main \& Berlin \& Bern \& New York \& Paris \& Wien: Peter Lang.

Zholobov, Oleg \& Krys'ko, Vadim 2001. Istoricheskaya grammatika drevnerusskogo yazyka. [Historical Grammar of the Ancient Russian Language.] T. II: Dvoystvennoye chislo. [Dual Number.] Moscow: Azbukovnik. 